\title{
A LINEAR PROGRAMMING APPROACH DETERMINING EMINENT DRIVERS OF CUSTOMER BASED BRAND EQUITY IN SPORTSWEAR INDUSTRY
}

\author{
G.N. Patel \\ Birla Institute of Management Technology \\ Greater Noida, India \\ E-mail: gn.patel@bimtech.ac.in \\ Richa Singh* \\ Birla Institute of Management Technology \\ Greater Noida, India \\ E-mail: richa.singh@bimtech.ac.in \\ Veenu Sharma \\ Birla Institute of Management Technology \\ Greater Noida, India \\ E-mail: veenu.sharma@bimtech.ac.in
}

\begin{abstract}
Along with its substantial part in business practices, brand equity is considered one of the significant concepts in academic world too. Creating and managing brand equity has been accentuated as an essential task for most of the firms. With Indian sportswear segment tramping its way in an upward movement, presence of number of national and multinational brands are seen contending for customer's attention and market share. This paper looks into the most eminent drivers of brand equity, from a customer-based point of view, in the Indian sportswear market. We present an approach based on linear programming (LP) generated within the framework of the analytical hierarchy process (AHP). Sportswear industry offers products that provide more intangible value to its users than tangible characteristics, the proposed approach is chosen. Since it allows for pair wise comparison between non-directly measurable criteria, providing ranks to the intangible drivers of the brand equity. Data was collected by interviewing consumers as the customers are considered to be the experts when it comes to their purchase decision. The analysis also furnishes a global ranking for four sportswear brands: Nike, Reebok, Adidas and Puma
\end{abstract}

Keywords: Marketing Applications, Customer-Based Brand Equity, Sportswear, India, Analytical Hierarchy Process. 


\section{Introduction}

Brands are ubiquitous; they play a significant role in the success of companies. Brands are considered to be an important driver for converting people into consumers. They are the modifier gene of a product or service in the minds of the customer. Brand image can affect the buying behavior of the consumers.

Due to the ever changing consumers' tastes and preferences, managements of these brands have become complex. Increased in the number of sports events happing across the world and people becoming more and more health consciousness have resulted in the growth of sportswear industry.

The shift in the usage of sportswear products by its consumers is assumed to be the reason behind the growth of sportswear market. Earlier sportswear was used substantially for sporting activities, but people have also started using it as casual wear too. Therefore the popularity of sportswear is experiencing continuous hike, thus promising tremendous scope of business to sportswear companies.

Although number of study have already been done on retail sector, but still there do not exist much on the sportswear retailing. Secondary data on the sportswear sector is abundant for Chinese and US market, but despite the growing sportswear market in India, gathering information about Indian sportswear market was an uphill battle. In spite of the fact that Indian sportswear market is so promising and ever growing, the question that how a sportswear company build effective brand equity remains under-researched.

In the present scenario, with competition growing day by day, branding remains the first choice of the multinationals to create a competitive edge for their brands. Thence, developing and managing brand equity plays a strategic key role in gaining competitive advantage in the market.

Customers' purchase intension can be so complex that a Channel handbag would be strongly desired for its power to categories the buyer to a particular social group, more than for its design or quality of material. Thus, it becomes essential for the brand owners to know what drives their consumers to buy their products.

\section{Literature review}

\subsection{Brand equity}

Brand equity is widely considered as an important intangible asset of a company therefore creating and managing it is a wise investment. Companies such as Amazon.com, Coca Cola, and eBay, are believed to be overestimated of its worth more because of this intangible asset rather than other measurable tangible benefits they have (Interbrand, 2006).

Brand equity has been defined differently by different authors; some defined it from a psychological point of view with an assumption that brand equity is developed in the mind of customers. Others define it from a financial perspective saying. Brand equity is 
"the added value to the firm, the trade, or the consumer with which a given brand endows a product" (Farquhar 1989).

But perhaps definitions coined by the authors who are most widely accepted are those of Aaker (1991) and Keller (2003). The former defines brand equity as "a set of brand assets and liabilities linked to a brand, its name and symbol that add to or subtract from the value provided by a product or service to a company and/or to that company's customer" (Aaker, 1991). Keller (2003) defines consumer-based brand equity (CBBE) as "the differential effect that brand knowledge has on consumer response to the marketing of that brand".

\subsection{Brand equity Models}

Literature available shows that there are researchers who argue for a conceptualization of brand equity based on five factors: social image, attachment, performance, trustworthiness and brand value (Lassar et al., 1995). Some other advocate for four different dimensions: brand loyalty, brand awareness, brand associations and perceived quality (Aaker 1991). And according to Keller's (2003) CBBE model, brand equity is the result of two factors: brand awareness and brand image.

Furthermore, brand equity has been proved positively related to gaining market share (Agarwal and Rao 1996), price insensitivity (Erdem T, et. al 2002), purchase intensions and consumer preference (Cobb-Walgren CJ, et. Al, 1995), capability of earning high profit margin (Ailwadi, et.al, 2003) and supportive in brand extension ( Pitta and Katsanis, 1995). Even after such widely studied problem, research approaches have been ignoring few of the aspects of business and often rely on less objective indicators.

Some of these limitations can be well handled by use of the Analytic Hierarchy Process (AHP) by which we can prioritize the drivers of brand equity.

\subsection{Analytical Hierarchy Process (AHP)}

AHP is a decision making tool developed by Saaty (1977) which is widely used for solving complex decision problems. It works on multi-level hierarchical model comprising of objective, criteria, sub-criteria and alternatives.

Consumers are allowed to rank their decision making elements even when they are not totally conscious or rational. To the point data are derived by using a number of pairwise comparisons. These comparisons are then used to obtain the weights for criteria and the relative performance measures of the alternatives in terms of each individual decision. AHP provides its benefit effectively when the decision problem involves both qualitative and quantitative elements.

AHP is widely used in various fields of research comprising of: banks (Haghighi, et al, 2010), manufacturing systems (Yang, Chuang, \& Huang, 2009), site selection (Önüt, Efendigil, \& Soner Kara, 2009), evaluation of website performance (Liu \& Chen, 2009), strategy selection (M. K. Chen \& Wang, 2010), new product development (Ayag Z 2005). However, there are barely any application for measuring brand equity, with just a few examples, such as that carried out by Costa and Evangelista (Costa 2008).

\section{Hypotheses/objectives}


The main objective of the investigation is to uncover the most eminent drivers of consumer-based brand equity (CBBE). The study would be of some help to the brand managers by providing some insight about customers' reason of choosing a particular brand of sportswear. They might take into account, the present study, when aiming to increase their brand value.

\section{Research design/methodology}

To determine the weights of the comparison matrix we have used two stage linear programming (LP) process. In the first stage we have formulated the LP which provided consistency bond. In the second stage the consistency bond obtained in the first stage were used to set the weights.

\section{Data/model analysis}

Brand equity drivers were partially adopted from research done by Battistoni $\mathrm{E}$, Colladon AF and Mercorelli G (2013), and some of them were added after the brainstorming session with groups of postgraduate students who were having some experience of marketing and brand management.

1. Brand reputation

1.1. Sports event sponsored by the brand

1.2. Company history

1.3. Online reputation or Search Engine Results Page (SERP)

1.4. Reputation of Sportsperson/Celebrities associated with brand

2. Offered products and services

2.1. Reliability

2.2. Packaging

2.3. Quality

2.4. Ease of use

2.5. Durability

2.6. Design of product

3. Communication strategies

3.1. Media coverage

3.2. Advertising expenditure

3.3. Emotional value of the brand

3.4. Presence on Social Media

3.5. Point of sale or showroom design

3.6. Interaction with customers

3.7. Corporate Social Responsibility

4. Logo

4.1. Design

4.2. Ability to recognition

5. Consumer base

5.1. Presence in international markets

5.2. Market shares 
5.3. Availability of product

5.4. Extent of product range

6. Strategies for building customer loyalty

6.1. Attention paid to customers' feedback

6.2. Loyalty programmes

6.3. After-sale services

\section{Pricing}

\section{Limitations}

The study only focuses on the driver of brand equity from customers' point of view. Brand equity drivers from financial perspective have been totally excluded. Limitations of LP is applicable here, because we are using LP approach of AHP here.

\section{Key references}

Aaker DA.(1991). Managing Brand Equity: Capitalizing on the Value of a Brand Name. New York: Free Press. p330.

Battistoni E, Colladon AF and Mercorelli G (2013). Prominent Determinants of Customer-Based Brand Equity. International Journal of Engineering Business Management. 5

Chandran B, Golden B and Wasil E. (2005). Linear Programming Models for Estimating Weights in the Analytic Hierarchy Process. Computes \& Operations Research. 32. 2235.

Keller KL. (1993). Conceptualizing, Measuring, and Managing Customer-Based Brand Equity. Journal of Marketing. 57 (1). 635.

Saaty T. (1977). A scaling method for priorities in hierarchical structures. Journal of Mathematical Psychology. 15. 234. 